\title{
Achievement Analysis Seen From Psychology Athlete Factors In Kein Shin Kan Karate-Do College Of North Sumatera
}

\author{
Anggi Erna Yani Siregar \\ Department Of Sport Education \\ Post Graduate Program, State University Of Medan \\ Medan, North Sumatera, Indonesia. \\ ernayanianggi@gmail.com
}

\begin{abstract}
This research was conducted at Kei Shin Kan Karate-do College of North Sumatra Province. This research is planned to be implemented starting from October 2018. The method in this research is descriptive verification, by using ex post facto survey approach. Based on the type of data analyzed, this research is classified into quantitative research, ie research whose data is in the form of numbers or qualititive data that is suspected. Based on the theoretical framework and framework of thinking above, then the hypothesis is drawn in this study as follows: 1) Direct Influential Motivation Against Self-Confidence Athlete Kei Shin Kan Karate-do University of North Sumatra. 2) Direct Influential Anxiety Against Self-Confidence Athlete Kei Shin Kan Karate-do University of North Sumatra. 3) Direct Influential Motivation Against Achievement of Athlete at Kei Shin Kan Karate-do University of North Sumatra. 4) Anxiety Direct Influence To Achievement Of Athlete Perguruan Kei Shin Kan Karate-do North Sumatra. 5) Self Confidence Directly Influence Against Achievement athletes of Kei Shin Kan Karatedo University of North Sumatra.
\end{abstract}

Keywords : Sport Psychology, Karate, Psychology.

\section{INTRODUCTION}

Along with the many matches being held, karate sports achievements in Indonesia experienced very rapid development. The parameters of the progress of the sport can be seen from the results of the championships that were followed by Indonesian karateka at regional and international levels. The achievement improvement is inseparable from training and coaching that is programmed with a scientific coaching method approach.

Based on observations made at Kei Shin University Kan Karate-Do North Sumatra that researchers found some data such as from 2007 to 2016 athletes' performance showed a significant decrease, even though Kei Shin Kan Kanate Do North Sumatra consists of several pengcab and many trained athletes. Logically perceptions of achievement must be very good but on the contrary each year athletes' performance decreases. Then if viewed in terms of coaching it is also quite good where the athlete is fostered with adjusted time. But there are some aspects that are not affordable for the coach or coach, namely the psychological aspect of the athlete.

When viewed from 2007 to 2013 when viewed from the data of the most advanced athletes as representatives of Forki North Sumatra in 2009 and the fewest in 2012, according to the competitiveness coach to become a representative of Forki it was quite fierce where many athletes from other universities also indeed achievers. If you see the gold medal, the most is obtained in 2007 and in 2013 and 2014 there was no gold medal at all. Then followed the highest number of silver in 2009 and the most bronze in 2007. Then in 2014 to 2017 where in 2017 there were 2 championships and in 2014 the medals were only bronze 3 and medals were not obtained at all. In 2015, many Kei Shin Kan representative athletes were revealed as many as 16 people but 2 silver and 2, bronze 3 . In 2016 athletes were dropped by 15 people and 1 silver and 2 bronze medals. In 2017 there was a significant decline where only 1 athlete was sent and received 1 bronze. The decline in athlete's achievement is due to many factors, especially in 2017 , only 1 athlete who was revealed as a representative of Forki and according to the coach, there are many things that must be addressed in the program, schedule, management and the role of trainers in improving athletes' performance.

2017 is the year that has the least number of athletes at the Forki representative, this can be seen from the curve above. The athlete's achievement decreases due to the coach or athlete saying that his failure in achieving the set achievement is due to psychological factors. They feel that physical training, techniques and strategies that have been done so far are optimal and during training the athlete shows high motivation to be able to achieve the expected performance, but before selection and competition the athlete starts to worry, difficult to concentrate and become less confident. 
Athletes also recognize that many high-quality athletes go down in selection and competition, and they are aware of the shortcomings in each individual.

Based on an interview from one of the trainers at Kei Shin Kan Karate-do, North Sumatra, Mr. Ridho Illah, where he stated that the athlete's performance was decreasing due to several things, for example in the psychic of the athlete who had enough influence. He said the decreasing motivation of athletes to improve achievement after being recruited and becoming trained athletes is indicated by the athlete's motivation which can be caused by factors that come from within the athlete (intrinsic / internal) and from outside the athlete (extrinsic / external), this can seen from medal acquisition during the match.

Then another thing according to the coach is excessive anxiety and lack of confidence when competing. Athletes experience symptoms of anxiety and stress in a match such as anxiety, worry, tension, confusion, lack or loss of concentration and decreased confidence in a race. Confidence can be interpreted to do or do something the best action. One of the factors that causes frequent failure in a match is lack of emotional control so that it affects the athlete's mentality itself

The influence of mental factors (psychic) on athletes is specifically seen when competing. It can be seen, among others, the strong weak drive to achieve and win the match. Mental factors that sometimes have a big effect on an athlete even if an athlete has prepared the physical factors as well as possible, prepare the equipment as well as possible, prepare the technique as well as possible but if there is less encouragement to achieve often the results will be disappointing.

Based on the description above, the researcher was interested in researching about the achievements of karate athletes at Kei Shin University Kan Karate-do in North Sumatra in this case namely motivation, anxiety and confidence. This is aimed at the success of the program and achievement of athletes in the future and input for all pencab, college and PB FORKI

After tracing the above, it can be understood about the meaning of the word achievement. Achievement is basically a process that results in changes in the individual, namely achievement. Thus, achievement is the result obtained in the form of impressions that result in changes in the individual as a result of an activity.

From the description above, it is quite clear to us that the mastery of exercise skills and achievement in various frames according to the sports domain in question are the main elements. According to Rusli Lutan (1988: 13) briefly the factors that influence achievement are: 1) endogenous factors and 2) exogenous factors.

Endogenous factors are attributes or characteristics inherent in a person's physical and psychological aspects, while exogenous factors are defined as all factors outside the individual, both those found in the environment where they practice and in a more general environment. Its understanding is like the physical environment, economic geography, social and culture even the tradition of activities inherent in a particular community environment.

There are so many factors that determine the achievement of a sporting achievement. According to Sajoto (1988: 2) that in order to achieve sports performance, it is an effort that is truly calculated carefully with a coaching effort, through an early nursery, and an increase in achievement through a related scientific approach.

Problems that occur in the world of sports in the country is a systemic problem, which means that the problems are interconnected and interdependent which cannot be understood in a fragmented methodology which is a characteristic of academic discipline and characteristics of government and non-government bodies . Increasing competition in the world of competitive sports demands sincere willingness from sports people in the country to receive and implement advances in sports science and technology, including accessing new information and innovative thinking about sports coaching. The trainers and coaches must immediately change the attitudes and behavior of training and guidance from traditional to training concepts and coaching that utilize the advancement of sports training science and technology. They must have the desire and courage to change (willing to change), quickly absorb, manipulate, and adjust to the acceleration of the transmission of world progress. Those who do not have the will and courage will be increasingly left behind.

It was further indicated that the main focus of the training program for Indonesian athletes was still on the physical, technical and tactical aspects, and ignored the psychological skill factors that could actually help athletes in improving their performance. In terms of managing stress felt during the match, the student hockey athletes who were used as research samples turned out to have a low level of effectiveness in dealing with stress; that means they use coping techniques that are contrary to what they should do according to the stressful situation at hand.

In the history of sports psychology, the name Wilhelm Wundt cannot be ignored. He carved his name as the founder of the First Psychology Laboratory in Leipzig, Germany. Then the Father of Sports Psychology namely Griffth according to Singgih (1989: 13).

According to Singgih (1989: 14) the appearance of an athlete in a game or match cannot be separated from the behavior and psychological aspects underlying it. Physical conditions that include strength and flexibility of muscles, structure, anatomical physiology, technical skills are factors that influence performance and achievement. However, physical conditions alone are not enough because there must be someone who drives, directs so that appearance is a 
combination of several factors where psychological factors often play a major role (in Singgih, 1989: 14).

Motivation according to Anshel in Komarudin (2016: 23) is a tendency to the direction and selectivity and behavior that is supervised with its connection to the consequences, and its tendency to maintain the goal until it is achieved. The purpose of "direction" refers to the specific direction, activity, or target chosen, is the athlete always looking for, approaching, or interested in a particular situation? For example, the trainer follows the training of athletes to go to tennis, injured athletes go to medical rehabilitation. This shows the direction of the behavior of the athlete and the coach in question to do something.

According to Singgih (1989: 147) anxiety is a feeling of helplessness, insecurity without a clear, blurred or vague cause. Anxiety in the match will cause excessive emotional pressure that can interfere with the performance of the match and affect appearance or achievement. As according to Levitt quoted by Husdarta (2010: 73), "anxiety can be defined as a subjective feeling of fear and increase physiological excitement." Everyone has experienced anxiety or fear of various situations such as fear of being scolded, afraid of not going to class, afraid failed, afraid of being hit and afraid or worried before competing.

From the various opinions of experts as described, the researchers can draw the conclusion that the definition of anxiety is a feeling that is often experienced by someone in this case the athlete, can cause emotional stresses include; anxiety, worries, and fear of something that is not clear that happens at a certain time, for example when facing a match. This feeling of anxiety arises in the athlete can be caused by intrinsic factors or extrinsic factors that can interfere with the implementation of the match to be faced so that it can affect the appearance of the athlete in the face of a match.

Athletes who do not have confidence will doubt the abilities possessed by him, so that athletes become tense and desperate in facing their duties (Komarudin, 2016: 65). This situation will harm athletes to display their best performance. Likewise athletes who have excessive confidence will also be detrimental to him because athletes always have hope and optimism that are too high to succeed. This situation will have a negative impact on athletes, including athletes who will experience frustration because what athletes expect is often different from reality.

\section{METHOD}

This type of research is descriptive verification survey method according to Riduwan (2004: 56) is research conducted on large and small populations, but the data studied is data from samples taken from the population so that relative events, distributing, and relationships between variables are found. Based on the type of data analyzed, this study is classified as quantitative research, namely research in which the data is in the form of numbers or data that is expected.

\section{RESUlt AND DiscUSSION}

TABLE 1 Athlete Kei Shin Kan Medan is excellent

\begin{tabular}{|c|c|c|c|}
\hline No & Nama Atlet & Usia & Kelas \\
\hline 1 & $\begin{array}{c}\text { Berkat Anugerah } \\
\text { Tampubolon }\end{array}$ & 22 Tahun & $\begin{array}{c}\text { Senior }-78 \mathrm{Kg} \\
\text { (Kumite) }\end{array}$ \\
\hline 2 & Putra Pratama Sitorus & 21 Tahun & $\begin{array}{c}\text { Junior }-57 \mathrm{Kg} \\
\text { (Kumite) }\end{array}$ \\
\hline 3 & M. Alwi Hsb & 24 Tahun & $\begin{array}{c}\text { Senior }-60 \mathrm{Kg} \\
\text { (Kumite) }\end{array}$ \\
\hline 4 & Adrian & 20 Tahun & $\begin{array}{c}\text { Senior }-84 \mathrm{Kg} \\
\text { (Kumite) }\end{array}$ \\
\hline 5 & Ulfa Zahara & 19 Tahun & $\begin{array}{c}\text { Senior }+59 \\
\text { Kg(Kumite) }\end{array}$ \\
\hline 6 & Sartika Despita Sagala & 18 Tahun & $\begin{array}{c}\text { Junior Putri }-50 \\
\text { Kg (Kumite) }\end{array}$ \\
\hline 7 & M. Iqbal & 18 Tahun & $\begin{array}{c}\text { Junior }-57 \mathrm{Kg} \\
\text { (Kumite) }\end{array}$ \\
\hline 8 & M. Aidil Febri & 17 Tahun & $\begin{array}{c}\text { Kadet }-52 \mathrm{Kg} \\
\text { (Kumite) }\end{array}$ \\
\hline 9 & Gibreka Nadika Ginting & 18 Tahun & $\begin{array}{c}\text { Junior }-57 \mathrm{Kg} \\
\text { (Kumite) }\end{array}$ \\
\hline 10 & Egi Wirasyanda & 17 Tahun & $\begin{array}{c}\text { Junior }-57 \mathrm{Kg} \\
\text { (Kumite) }\end{array}$ \\
\hline 11 & Ade Putri & 18 Tahun & Junior $-50 \mathrm{Kg}$ \\
\hline 12 & M. Fajar & 16 Tahun & $\begin{array}{c}\text { Kadet }-52 \mathrm{Kg} \\
\text { (Kumite) }\end{array}$ \\
\hline
\end{tabular}

Dalam penelitian ini, peneliti menentukan syarat yang akan menjadi sampel penelitian adalah atlet karate dari perguruan Kei Shin Kan Pengcab Medan yang berprestasi. Dalam hal ini terdapat 12 atlet dari Kei Shin Kan Sumatera Utara yang berprestasi mewakil Forki Sumut.diagram batang, histogram, grafik garis dan distribusi frekwensi.

Data yang telah dikumpulkan selanjutnya diolah dan dianalisis dengan teknik statistik analisis jalur (path analisys). Untuk memperoleh mengolah data digunakan alat bantu komputer statistik SPSS. Persyaratan untuk menggunakan analisis jalur adalah : 1) hubungan antara variabel harus linier, 2) pola hubungan antar variabel adalah rekursif, 3) data berdistribusi normal atau mendekati normal, 4). Tidak terjadi heterokedasitas. Penelitian ini adalah jenis deskriptif dengan menggunakan instrument mempunyai data interval, oleh karena itu grafik yang digunakan adalah

\section{CONCLUSION AND SUGGESTION}

As for the conclusions in this study are:

1) To find out the motivation of Kei Shin athletes in Kan Karate-Do North Sumatra.

2) To find out the anxiety of Kei Shin Kan Karate-Do North Sumatra college athletes. 
3) To know the confidence of Kei Shin athletes in Kan Karate-Do North Sumatra.

4) To find out the achievements of Kei Shin college athletes Kan Karate-Do North Sumatra.. Based on the implementation of this research it is recommended: 1) For the trainer, important psychic things are known because by knowing the causes and ways to improve the athlete's performance, it will also increase the athlete's achievements at Kei Shin Kan Karate-do University in North Sumatra. 2) For sports coaches as authorities in giving advice to the coach. The results of this study are expected as input material in karate sports coaching so that it can be considered when viewed from the psychic point of view of the athlete. 3) For PB Forki, this research is expected to be a consideration in karate sports coaching. 4) For researchers, the results of this study can be used as a reference for the next and can be developed with other variables.

\section{REFERENCES}

[1] Dimyati, Herwin. 2013. Karakteristik Psikologis Atlet Pusat Di Pusat Pendidikan dan Latihan Pelajar (PPLP). Jurnal Psikologi. Vol 40. No. 2.

[2] Gunarsah Singgih, Monty.P.S, Myrna H.R.S. 1989. Psikologi Olahraga: Teori dan Praktek,Jakarata : BKM-Gunung Mulia.

[3] Harsono. 1988. Aspek-aspek Psikologi dalam Coaching. Jakarta: CV. Tambak Kusuma Jakarta.

[4] Husdarta, (2010). Psikologi Olahraga. Bandung: Penerbit Alfabeta

[5] Komarrudin. 2016. Psikologi Olahraga. Bandung: Remaja Rosdakarya.

[6] Rusli Lutan. 1988. Belajar Ketrampilan Motorik Pengantar Teori dan Metode. Jakarta: Depdikbud. Dirjendikti.

[7] Sajoto, Mochamad. 1988. Pembinaan Kondisi Fisik Dalam Olahraga. Jakarta: Departemen Pendidikan dan Kebudayaan.

[8] Santosa Giriwijoyo, Mucthamadji M,Ali. 2005. Buku Ilmu Faal Olahraga, Bandung : Fakultas Pendidikan Olahraga dan Kesehatan UPI 